On what basis does Nasser bracket Szasz with Cooper and Laing? Szasz has always written from the position of right wing libertarianism whereas Cooper and Laing were on the left wing of politics. Even linking Cooper and Laing in this way is suspect if we take Mullan's (1995) record of conversations with Laing as accurate. Here Laing's promiscuous interest in liberal thinkers contrasts with his portrayal of Cooper as a committee communist activist in exile.

Is there shared thinking between the three? One footnote apart, Szasz makes no mention of Laing or anti-psychiatry until Insanity: The Idea And Its Consequences (1987). Here he castigates Laing for claiming to be a doctor of non-illnesses. Laing appears to confirm Szasz's antagonism when reporting one encounter to Mullan (op. cit.). Prior to the Mullan publication Laing and Cooper only mention Szasz in three footnotes.

Arguably Szasz, Cooper, and Laing can be grouped as critics of orthodox psychiatry but can hardly be characterised as sharing any kind of platform.

These comments may be dismissed as debating points, but my main interest is in important questions implicit in Nasser's letter: Is critique of our work always to be experienced paranoically, as the barbarian at the gates? If self-critique by psychiatrists is to be routinely savaged should we dismiss out of hand the considered views of fellow professionals from other disciplines? Should we make the reflex assumption that representatives of MIND are engaged in a relentless moral crusade against all our profession stands for?

BOYERS, R. \& ORRIL, R. (1971) Laing and Antt-Psychiatry. Harmondsworth: Penguin.

COOPER, D. (1970) Psychiatry and Antt-Psychiatry. St. Albans: Paladin.

LAING, R. (1985) Wisdom, Madness and Folly. London: Macmillan.

Mullan, R. (1995) Mad To Be Normal: Conversations With R. D. Laing. London: Free Assoctation Books.

Szasz, T. (1987) Insanity: The Idea And Its Consequences. New York: Wiley.

J. BIRCH, Kiln Riggs, Hexham, Northumberland NE46 4EQ

Sir: I stated that the anti-psychiatric movement grew in the realm of politics, particularly of the left. I did not say however that Szasz belonged to the left. Szasz's political views were seldom made obvious (Sedgwick, 1982). His views were commonly regarded as libertarian, anti-collectivist that focused mainly on the individual. Some saw an inherent contradiction in Szasz's political argument as he appeared more to the right than the prevailing capitalist structure that was the subject of his attack. My inclusion of Szasz with Cooper and Laing was unrelated to his political ideology, more that he belonged to the antipsychiatric movement and his premise was largely in keeping with that of Laing and Cooper.

It is difficult to see that the anti-psychiatric movement only represented a different view point or an antithesis that was not hostile to psychiatry. In Cooper's language of madness, he says

"most victims of supposed madness, suicide are made victims by those who compulstvely have to help . . . were it not for the stigmatisation, the institutionalising process, and the interference of doctors who have to justify their exdstence by the medical game of diagnosis, shocks and chemical euthanasia" (Cooper, 1980).

It is regrettable that the anti-psychiatric movement did not evolve or develop into a real antithesis to provide a much needed alternative view. It has certainly contributed in the past to lively debates about the nature of psychiatry and been probably instrumental in shaping existing psychiatric services.

The new community facilities have to a great extent rendered the psychiatrist physically and intellectually isolated. There is therefore a need to look at the structure of the training of other mental health professionals as well as our own. The point is to not live in the past, entertaining scientifically unfounded beliefs or indeed thinking only in terms of neurotransmitters. What is needed is to encourage the development of a discourse to enable the expression of other views, which are truly vital to the current state of psychiatric practice and its future.

COOPER, D. (1980) The Language of Madness. London: Pelican.

SEDGWICK. P. (1982) Psychopolitics. London: Pluto Press.

M. NASSER, University of Leicester, Leicester Royal Infirmary, Leicester LE2 7LX

\section{Leave and detained patients}

Sir:

"Many still believe, incorrectly, that a detained patient may go on leave without the completion of Section 17 leave formalities if they are only going out of the hospital grounds for a short while or if they are escorted by staff."

"Section 17 applies to the shortest period of absence. ...."

These quotations from the 6th Biennial Report of the Mental Health Act Commission (MHAC) are perfectly clear-as long as we know what "hospital grounds" are. The term "hospital" is finally, unhelpfully, defined in Section 145, of the 149 Sections, in the 1983 Mental Health Act; grounds are not. "What is a hospital?" asks MHAC Practice Note 3, 1994. The question may 